Original Research Article

\title{
Evaluation of analgesic activity of turmeric (Curcuma longa Linn.) in Wister rats
}

\author{
Sangita Jogdand, Jagruti Bhattacharjee*
}

Department of Pharmacology, Jawaharlal Nehru Medical College, Sawangi (Meghe), Wardha, Maharashtra, India

Received: 28 December 2016 Accepted: 01 February 2017

\section{*Correspondence to:}

Dr. Jagruti Bhattacharjee, Email: jagrutib@yahoo.com

Copyright: (C) the author(s), publisher and licensee Medip Academy. This is an openaccess article distributed under the terms of the Creative Commons Attribution NonCommercial License, which permits unrestricted noncommercial use, distribution, and reproduction in any medium, provided the original work is properly cited.

\begin{abstract}
Background: NSAIDs like Aspirin etc. are randomly used for mild to severe types of pain but long-term and injudicious use of NSAIDs lead to a number of side effects. The present study is designed for exploring the analgesic potential of Curcuma longa Linn (Turmeric) in albino rats, which may widen the therapeutic horizon for the said agent.

Methods: Ethanolic extract of Curcuma longa in the doses 100, 200 and $400 \mathrm{mg} / \mathrm{kg}$ is given orally to $6 \mathrm{Wister}$ rats against a control of normal saline and a standard using Aspirin (300mg/kg) and the animals were subjected to Eddy's hot plate test at different time intervals i.e., 30, 60, 90 and 120 minutes after administration of the drugs and the parameters were noted.

Results: The analgesic activity of Curcuma longa showed significant $(p<0.05)$ increase in mean basal reaction time in Hot plate method when compared to the control (Normal saline). As the dose of the ethanolic extract of Curcuma longa was gradually increased from 100, 200 and $400 \mathrm{mg} / \mathrm{kg}$ respectively, the analgesic activity significantly increased $(<0.05)$. Effect of curcuma longa at a dose of $400 \mathrm{mg} / \mathrm{kg}$ is found to be comparable with Aspirin.
\end{abstract}

Conclusions: The results of this study suggest that turmeric (Curcuma longa) has significant analgesic activities in rats.

Keywords: Analgesic, Curcuma longa, Hot plate experiment, Turmeric

\section{INTRODUCTION}

Curcumin, a member of the ginger family Zingiberaceae; (1,7-bis [4-hydroxy-3-methoxyphenyl] -1,6- heptadiene3,5-dione) is a hydrophobic polyphenol compound. It is found in the rhizome of the herb Curcuma longa Linn., which is commonly known as turmeric. ${ }^{1}$ Turmeric is widely used in therapeutic preparations against anorexia, rhinitis, herpes zoster, acne, cough, urinary tract diseases, diabetic wounds, hepatic disorder, rheumatism and sinusitis. ${ }^{1-3}$ Curcumin has several properties including antioxidant, antimicrobial, anti-inflammatory, antiviral, anti-carcinogenic and anti-diabetic activities. ${ }^{4-9}$ Recent studies have shown that curcumin also suppresses neuropathic pain induced by chronic sciatic nerve ligation. $^{11}$

Commonly NSAIDs are randomly used for mild to severe types of pain but long-term and injudicious use of NSAIDs lead to a number of side effects like peptic ulcerations, asthma, abdominal pain, abnormal liver functions tests, renal insufficiency etc. ${ }^{10}$ So, there has been a continuous search for a better alternative to NSAIDs, which will suppress the symptoms of pain as well as will be well tolerated in the body without showing much adverse effects.

Studies have been continued regarding the analgesic property of turmeric but no standard results are being obtained. $^{2}$ Furthermore, Curcuma longa has shown properties which prevent hepatic toxicity. ${ }^{3}$ So, it can also be used with common analgesics like Paracetamol etc, which in high doses are fatal for the liver. Curcuma longa Linn., which is widely used as turmeric in cooking Indian foods, is well tolerated in the human body. 
Hence the present study is designed for exploring the analgesic activity of Curcuma longa Linn. in Wister rats and to compare the analgesic activity of Curcuma longa Linn with Aspirin which may widen the therapeutic horizon for the said agent.

\section{METHODS}

Study design of the study was preclinical experimental study.

The study was conducted at Research Laboratory and Animal House, Department of Pharmacology, JNMC.

Duration of the study was 6 months (January 2016 to July 2016).

\section{Preparation of the extracts}

Ethanolic extract of turmeric prepared in the Central Research Laboratory of JNMC was administered to the animals orally.

\section{Animals required}

Healthy, albino rats (150-250gm) twelve weeks old of either sex, bred locally in the animal house of JNMC, Sawangi (Meghe) were used for the study. They were housed under controlled condition of temperature $23 \pm 2{ }^{\circ} \mathrm{C}$ and 12 hour light and dark cycles respectively. The animals are maintained on normal diet and water $\mathrm{ad}$ libitum. Animals are grouped into 5 of 6 animals each $(n=$ 30).

\section{Rationale for the use of animals}

Since these are preliminary studies, the activity of above said drug was confirmed by animal experiments. As the rats were easy to handle, easily available, easy to subject them to testing and their nutrition resembles that of human so, they were preferred for the usage for present study

The animals were allocated randomly into 5 groups of 6 animals each as follows:

- Group I will receive normal saline $(\mathrm{NaCl}) 0.5 \mathrm{ml}$ serve as control

- Group II will receive Aspirin 300 mg/kg - serve as Standard

- Group III received ethanolic extract of Curcuma longa $100 \mathrm{mg} / \mathrm{kg}$ orally

- Group IV received ethanolic extract of Curcuma longa $200 \mathrm{mg} / \mathrm{kg}$ orally

- Group V received ethanolic extract of Curcuma longa $400 \mathrm{mg} / \mathrm{kg}$ orally

- Groups III, IV and V served as test groups.

The animals were subjected to the Eddy's hot plate test at different time intervals i.e., 30, 60, 90 and 120 minutes after administration of the drugs and the parameters were noted.

\section{Eddy's hot plate method}

Reaction time in seconds was used as the unit for measurement of pain and an increase in reaction time was indicative of analgesia. Time between placing the rat on the hot plate maintained at 55 degrees and jumping or licking of paw were recorded as "reaction time". Cut off time of twenty seconds was imposed in all sets of experiments taken as maximum latency so as to rule out thermal injury while noting down the reaction time. In all the groups, Eddy's hot plate tests were performed prior to drug administration, and at 30, 60, 90 and 120 minutes after drug administration, and the reaction time at each time interval (test latency) were calculated.

\section{Statistical analysis}

Statistical analysis was done by using descriptive and inferential statistics using Students' unpaired and paired t-test and software used in the analysis was SPSS 17.0 version and $p<0.05$ is considered as level of significance.

\section{RESULTS}

In the present study, we have studied the analgesic effect of Curcuma longa where an increase in reaction time in Eddie's hot plate method was considered an important parameter of central analgesic activity by non-selective cox-inhibition.

Table 1 showed the average reaction time (in seconds) of the 5 groups of experimental animals at different interval of time. ANOVA test was applied, which showed that there was difference in the mean reaction time between and within the groups. Then Tukey post hoc test was applied, where we got a significant difference between each of the test groups (III, IV, V) with group I (Control: $\mathrm{NaCl}$, which meant Curcuma longa had significant analgesic property at different doses and at various time intervals.

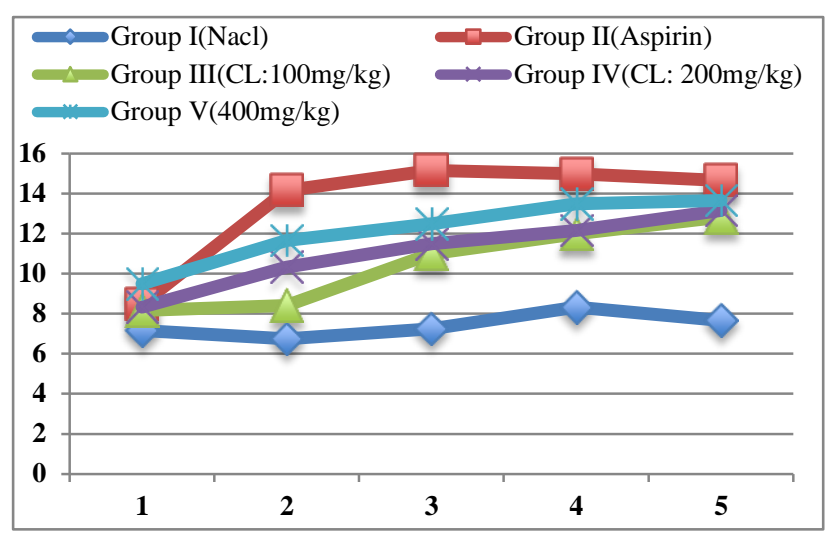

Figure 1: Findings from the hot plate test. 
Table 1: The average reaction time (in seconds) in the hot plate method.

\begin{tabular}{|c|c|c|c|c|c|c|}
\hline Group & & 0 min & $30 \mathrm{~min}$ & 60min & $90 \mathrm{~min}$ & $120 \mathrm{~min}$ \\
\hline \multirow{2}{*}{ I (Nacl) } & Mean & 7.2 & 6.7 & 7.2 & 8.3 & 7.7 \\
\hline & SD & 0.3 & 0.6 & 0.4 & 1.0 & 0.8 \\
\hline \multirow{2}{*}{ II (Aspirin) } & Mean & 8.5 & 14.2 & 15.2 & 15.0 & 14.7 \\
\hline & SD & 0.5 & 0.7 & 0.7 & 0.6 & 0.5 \\
\hline \multirow{2}{*}{ III (CL:100mg/kg) } & Mean & 8.2 & 8.4 & 11.0 & 12.0 & 12.8 \\
\hline & SD & 0.2 & 0.4 & 0.9 & 0.9 & 0.4 \\
\hline \multirow{2}{*}{ IV (CL:200mg/kg) } & Mean & 8.3 & 10.3 & 11.5 & 12.2 & 13.2 \\
\hline & SD & 0.5 & 0.5 & 0.5 & 0.7 & 0.4 \\
\hline \multirow{2}{*}{$\mathrm{V}$ (CL:400mg/kg) } & Mean & 9.5 & 11.6 & 12.5 & 13.5 & 13.7 \\
\hline & SD & 0.5 & 0.5 & 0.5 & 0.5 & 0.5 \\
\hline$P$ value & & 0.0001 & 0.0001 & 0.0001 & 0.0001 & 0.0001 \\
\hline $\begin{array}{l}\text { Significant pairs } \\
\text { (Tukey post hoc test) }\end{array}$ & & & $\begin{array}{l}\text { I and II, } \\
\text { I and III, } \\
\text { I and IV, } \\
\text { I and V }\end{array}$ & $\begin{array}{l}\text { I and II, } \\
\text { I and III, } \\
\text { I and IV, } \\
\text { I and V }\end{array}$ & $\begin{array}{l}\text { I and II, } \\
\text { I and III, } \\
\text { I and IV }\end{array}$ & $\begin{array}{l}\text { I and II, } \\
\text { I and III, } \\
\text { I and IV, } \\
\text { I and V }\end{array}$ \\
\hline
\end{tabular}

Table 2: Comparison of test group with Aspirin (Group II).

\begin{tabular}{|llllll|}
\hline Group & & Mean diff & Standard error & P value & 95\% CI \\
\hline \multirow{3}{*}{ II (30 min) } & III & 5.7 & 0.3 & 0.0001 & $4.8-6.7$ \\
\cline { 2 - 6 } & IV & 3.8 & 0.3 & 0.0001 & $2.8-4.7$ \\
\hline \multirow{3}{*}{ II (60 min) } & V & 2.5 & 0.3 & 0.0001 & $1.5-3.5$ \\
& III & 4.2 & 0.4 & 0.0001 & $3.0-5.3$ \\
\cline { 2 - 6 } & IV & 3.7 & 0.4 & 0.0001 & $2.5-4.8$ \\
\hline \multirow{3}{*}{ II (90 $\mathrm{Vin})$} & III & 2.7 & 0.4 & 0.0001 & $1.5-3.8$ \\
\cline { 2 - 6 } & IV & 1.0 & 0.4 & 0.002 & $0.6-3.3$ \\
\hline \multirow{3}{*}{ II (120min) } & V & 0.5 & 0.4 & 0.004 & $0.5-3.2$ \\
& III & 1.8 & 0.3 & 0.808 & $0.8-1.8$ \\
\cline { 2 - 6 } & IV & 1.5 & 0.3 & 0.0001 & $0.6-2.4$ \\
\hline
\end{tabular}

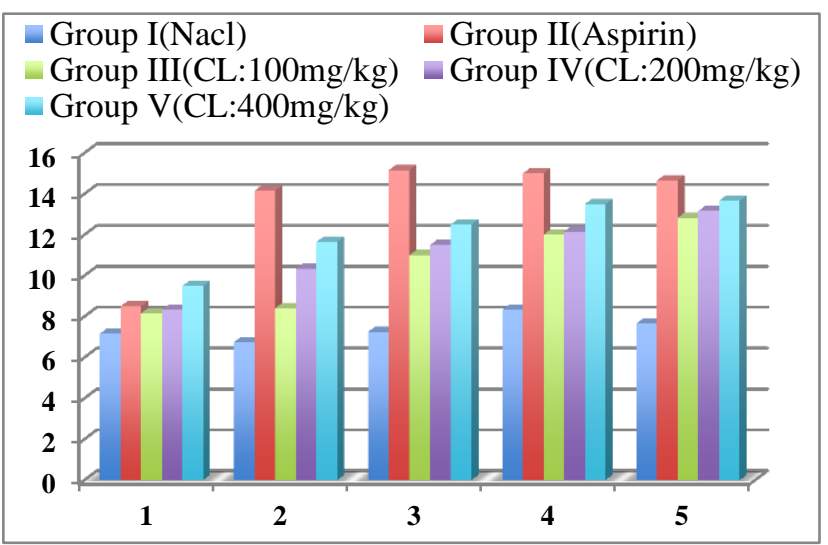

Figure 2: Mean reaction time of each group at different time intervals.

Figure 1 showed the findings from the hot plate test. It revealed increasing mean reaction time, of each test group (group III, IV, V) and the Standard (Aspirin) compared to the control group $(\mathrm{NaCl})$. We got a more vivid picture of the same findings in figure 2 , where the five groups were compared together at each time interval.

Table 2 showed the findings on comparing Aspirin (Group II) with the test groups (III, IV, and V), where we did not get any significant difference between Aspirin and Curcuma longa at $400 \mathrm{mg} / \mathrm{kg}$ (group V) at 90 and 120 minutes respectively. Hence, the analgesic activity of Curcuma longa at $400 \mathrm{mg} / \mathrm{kg}$ at 90 and 120 minutes was comparable with that of Aspirin.

\section{DISCUSSION}

We got significant analgesic activity at 100 and $200 \mathrm{mg} / \mathrm{kg}$ doses of Curcuma longa. These findings were found to be in conjunction with the studies conducted by John $\mathrm{S}$ et al and Neha $\mathrm{S}$ et al. ${ }^{11,12}$ In addition to 100 and $200 \mathrm{mg} / \mathrm{kg}$, we got a significant analgesic activity of Curcuma longa at $400 \mathrm{mg} / \mathrm{kg}$, comparable with Aspirin, which wasn't found in other studies. Another study 
conducted in China by Qing Zhu et al demonstrated chronic analgesic effects of Curcuma longa in postoperative pain in rat along with acute analgesic activity, which wasn't included in our study. ${ }^{13}$

In our study reaction time was noted for four time intervals only, where the analgesic effect of Curcuma longa was found to be rising. Few more readings could have helped in knowing the peak analgesic activity of Curcuma longa, which was our only limitation in the study.

\section{CONCLUSION}

From our study, we can conclude that Curcuma longa Linn. (Turmeric) has significant analgesic activity in rats and its analgesic activity at doses $400 \mathrm{mg} / \mathrm{kg}$ is comparable to that of aspirin at 90 and 120 minutes of administration respectively.

Funding: No funding sources

Conflict of interest: None declared

Ethical approval: The study was approved by the Institutional Ethics Committee

\section{REFERENCES}

1. Altenburg JD, Bieberich AA, Terry C, Harvey KA, Vanhorn JF, $\mathrm{Xu} \quad \mathrm{Z}$, et al. A synergistic antiproliferation effect of curcumin and docosahexaenoic acid in SK-BR-3 breast cancer cells: unique signaling not explained by the effects of either compound alone. BMC Cancer. 2011;11:149.

2. Devaraj S, Esfahani AS, Ismail S, Ramanathan S, yam MF. Evaluation of the Antinociceptive Activity and Acute Oral Toxicity of Standardized Ethanolic Extract of the Rhizome of Curcuma xanthorrhiza Roxb. Molecules. 2010;15:2925-34.

3. Soliman MM, Nassan MA, Ismail TA. Immunohistochemical and molecular study on the protective effect of curcumin against hepatic toxicity induced by paracetamol in Wistar rats. BMC Complementary and Alternative Medicine. 2014; 14:457.

4. Borra SK, Gurumurthy P, Mahendra J, Jayamathi, $\mathrm{KM}$, Cherian CN, Ram Chand. Antioxidant and free radical scavenging activity of curcumin determined by using different in vitro and ex vivo models. Academic Journals. 2013;36:2680-90.

5. Tajbakhsh S, Mohammadi K, Deilami I, Zandi K, Ramedani E, Asayesh G. Antibacterial activity of indium curcumin and indium diacetylcurcumin. Afr $\mathbf{J}$ Biotechnol. 2008;7:3832-5.

6. Bereswill S, Munoz M, Fischer A, Plickert R, Haag L, Otto B, et al. Anti-inflammatory effects of resveratrol, curcumin and simvastatin in acute small intestinal inflammation. 2010;5(12):e15099.

7. Kutluay SB, Doroghazi J, Roemer ME, Triezenberg SJ. Curcumin inhibits herpes simplex virus immediate-early gene expression by a mechanism independent of $\mathrm{p} 300 / \mathrm{CBP}$ histone acetyl transferase activity. Virology. 2008;373(1659):239-47.

8. Aggarwal B. The power of Curcumin. Hallelujah Diet. Health News. Available: from: http://www.myhdiet.com/healthnews/healthnews/the-power-of-curcumin/.

9. Aziz MT, El Ibrashy IN, Mikhailidis DP, Rezq AM, Wassef MA, Fouad HH, et al. Signaling mechanisms of a water soluble curcumin derivative in experimental type 1 diabetes with cardiomyopathy. Diabetol Metab Syndr. 2013;5:5-13.

10. John S, Nikhil S, Yaswanth J, Bhaskar A, Amit A, Sudha S. Analgesic property of different extracts of Curcuma longa (Linn.): An experimental study in animals. Journal of Natural Remedies. 2009;91:11620.

11. Katzung BG, Masters SB, Trevor AJ. Basic and Clinical Pharmacology. $11^{\text {th }}$ ed. New Delhi: Mc Graw Hill Medical; 2009:612-618.

12. Neha S, Ranvir GD, Jangade CR. Analgesic and antipyretic activities of Curcuma longa rhizome extracts in Wister Rats. Veterinary World. 2009;2(8):304-6.

13. Zhu Q, Sun Y, Yun X, Yuntao O, Zhang W, Jun-Xu L. Antinociceptive effects of curcumin in a rat model of postoperative pain. Scientific Reports. 2014,4;4932.

Cite this article as: Jogdand $\mathrm{S}$, Bhattacharjee $\mathrm{J}$. Evaluation of analgesic activity of turmeric (Curcuma longa Linn.) in Wister rats. Int J Basic Clin Pharmacol 2017;6:568-71. 